\title{
Device Over The Counter Product Indicator
}

National Cancer Institute

\section{Source}

National Cancer Institute. Device Over The Counter Product Indicator. NCI Thesaurus.

Code $C 93805$.

Specifies whether a device is available over-the-counter. 